SHAKESPEARE AND THE LOSS OF EDEN 
Also published by Palgrave Macmillan

The Feminist Reader, second edition, Catherine Belsey and Jane Moore (editors) 


\section{SHAKESPEARE AND THE LOSS OF EDEN}

The Construction of Family Values in Early Modern Culture

Catherine Belsey 
(C) Catherine Belsey 1999

Softcover reprint of the hardcover 1st edition 1999

All rights reserved. No reproduction, copy or transmission of this publication may be made without written permission.

No paragraph of this publication may be reproduced, copied or transmitted save with written permission or in accordance with the provisions of the Copyright, Designs and Patents Act 1988, or under the terms of any licence permitting limited copying issued by the Copyright Licensing Agency, 90 Tottenham Court Road, London W1P 0LP.

Any person who does any unauthorised act in relation to this publication may be liable to criminal prosecution and civil claims for damages.

The author has asserted her right to be identified as the author of this work in accordance with the Copyright, Designs and Patents Act 1988.

First published 1999 by

MACMILLAN PRESS LTD

Houndmills, Basingstoke, Hampshire RG21 6XS

and London

Companies and representatives

throughout the world

ISBN 978-1-349-15049-6 ISBN 978-1-349-15047-2 (eBook)

DOI 10.1007/978-1-349-15047-2

A catalogue record for this book is available from the British Library.

This book is printed on paper suitable for recycling and made from fully managed and sustained forest resources.

$\begin{array}{llllllllll}10 & 9 & 8 & 7 & 6 & 5 & 4 & 3 & 2 & 1\end{array}$

$\begin{array}{llllllllll}08 & 07 & 06 & 05 & 04 & 03 & 02 & 01 & 00 & 99\end{array}$

Copy edited and typeset in Book Antiqua by

Password, Norwich, UK 
To Alan and Cynthia

with love and thanks 
Previously published books by Catherine Belsey

Critical Practice

The Subject of Tragedy: Identity and Difference in Renaissance Drama John Milton: Language, Gender, Power

Desire: Love Stories in Western Culture 


\section{Contents}

List of Illustrations

Acknowledgements $\quad$ xi

Preface xiii

1 Introduction: Reading Cultural History 1

2 Desire in the Golden World:

Love's Labour's Lost and As You Like It 27

3 Marriage: Imogen's Bedchamber 55

4 Parenthood: Hermione's Statue 85

5 Sibling Rivalry: Hamlet and the First Murder 129

6 Postscript: Passion and Interpretation 175

$\begin{array}{ll}\text { Notes } & 179\end{array}$

Index 199 


\section{Illustrations}

1 Adam naming the animals, 'Bishops" Bible, 1578

2 The Fall, marriage chest, $1626 \quad 61$

3 The Creation of Eve, $1546 \quad 62$

4 Eve, bedhead 64

5 Adam, bedhead 65

6 The Fall, wedding or betrothal dish, $1635 \quad 67$

7 The Fall and the Expulsion, bed valance 69

8 Death and the Expulsion, bed valance 71

9 Hans Holbein the Younger, The Expulsion, $1538 \quad 72$

10 Death and the Fall, Jakob Rüff's treatise on childbirth, 158074

11 Jan Wierix, Taming the wilderness, 1607-8 86

12 Hans Holbein the Younger, The first family, 1538

13 Monument to Ralph Neville, Earl of Westmorland (d. 1484) and his wife $\quad 91$

14 Monument to Sir Lewis Mansell (d. 1638) and his wife 92

15 Monument to Ralph Greene (d. 1417) and his wife, Katherine 93

16 Monument to Giles Savage (d. 1631) and his wife, Catherine 93

17 Monument to John Bunce (d. 1611) and his wife, Dorothea (d. 1612)

18 Monument to William Knoyle (d. 1607) and two wives, Grace and Fillip

19 Monument to Sir Fulke Greville (d. 1559) and his wife, Lady Elizabeth (d. 1562)

20 Monument to Jane, Lady Waller (d. 1630s) 98

21 Monument to Jane, Lady Waller (d. 1630s) 99 
22 Monument to Edward Skynner (d. 1631) and his wife, Elizabeth

23 Monument to Giles Savage (d. 1631) and his wife, Catherine

24 Monument to Lady Margaret Legh (d. 1603) 109

25 The Cholmondeley Ladies, c. 1600-1610

26 Thomas Howard, Earl of Arundel (1618) displaying his statues

27 Brass monument to John Sea (d. 1604) and two wives, Martha and Sara

28 Monument to Sir Fulke Greville (d. 1559) and Lady Elizabeth (d. 1562)

29 Monument to Giles Savage (d. 1631) and his wife, Catherine, with William Savage

32 The first murder, 'Matthew' Bible, 1537

33 The infant Cain 133

34 Jan Wierix, The infant Cain, 1607-8 134

35 Cain and Abel, bed valance, 1604

36 The Dance of Death, ?1580 141

37 The Dance and Song of Death, 1569

38 Guyot Marchant, The Pope and the Emperor, La Danse macabre, 1485

39 Guyot Marchant, The Lawyer and the Minstrel, La Danse macabre, 1485

40 Guyot Marchant, The Queen and the Duchess, La Danse des femmes, 1486

41 Niklaus Manuel Deutsch, Death and a Young Woman, 1517151

42 Hans Baldung Grien, Death and a Woman 153

43 Hans Baldung Grien, Adam and Eve, 1531 


\section{Acknowledgements}

The author and publisher wish to thank the following for permission to use copyright material.

Figures 29, B. T. Batsford Ltd; 38, 39, 40, cliché Bibliothèque nationale de France; 36, 37, By permission of the British Library; 1, 9, 12, 32, By permission of the Syndics of Cambridge University Library; 13, 14, 17, 20, 21, 24, The Conway Library, Courtauld Institute of Art; 15, The Conway Library, Courtauld Institute of Art, Fred H. Crossley and Maurice H. Ridgway; 23, The Conway Library, Courtauld Institute of Art, Lawrence Stone; 3, 10, By permission of the Folger Shakespeare Library; 7, Glasgow Museums: The Burrell Collection; 11, 34, Kupferstichkabinett, Staatliche Museen zu Berlin - Preussicher Kulturbesitz; 8, The Metropolitan Museum of Art, New York, Gift of George R. Hann, 1960, and 35, The Metropolitan Museum of Art, New York, Gift of Irwin Untermeyer, 1964; 41, 42, Öffentliche Kunstsammlung Basel, Kunstmuseum. Photo: Öffentliche Kunstsammlung Basel, Martin Bühler; 43, Museo Thyssen-Bornemisza, Madrid; 26, By courtesy of the National Portrait Gallery, London; 31, From the Collection at Parham Park, West Sussex, England, open to visitors from April to October each year; 4, 5, 16, 18, 19, 22, 28, 30, Nicholas Prigg; 25, Tate Gallery, London, 1998; 6, 27, V\&A Picture Library; 2, Warwick Castle.

Thanks also to Ron Koster for the Holbein decorated capitals used throughout the book via his website at: http://www.psymon.com/ 


\section{Preface}

'Families,' a friend once told me, 'are the people who have to take you in - whether they like it or not.' Families are places of warmth and support; they are a constant feature in an unpredictable world; we can rely on them. At the same time, proximity may nurture hostility in direct proportion to the love it is supposed to take for granted. Precisely because of the high expectations families generate, they can be deeply disappointing. Worse, they can be abusive, both physically and emotionally.

In the course of the sixteenth century in England, the developing state discovered an investment in keeping the population in its sights, encouraging people to settle in stable groups, their relationships recorded in the parish register. Meanwhile, the parish itself, responsible for the survival of the poor, increasingly recognized the advantage of inducing two parents to stay together and support their children by the fruits of their own labour. And in the same period the Reformation clergy found it necessary to identify a new way of perfection to replace the now discredited monastic celibacy. Family values became the object of intense propaganda, and of the anxiety that the reconstruction of any value system necessarily creates.

We are the direct heirs of the early modern construction of family values, incited by politicians and moralists to believe, in the teeth of considerable counter-evidence, that the family will make us whole, both as individuals and as a society. But at the same time we are also experiencing an unprecedented anxiety about family values, in the course of acknowledging the limitations of the proposition that there is only one proper way to arrange our sexual relations, and in the process of learning from the statistics how commonly unhappiness can follow from the 
obligation of loyalty to those who have the greatest opportunities for brutality towards each other. Love, attributed to nature, can be more oppressive and more coercive than convention or law.

This book has three main aims. The first is thematic: to historicize and thus denaturalize family values. Whatever is customary comes in due course to seem natural. Moreover, since in a free society the explicit imposition of norms and regularities appears authoritarian and thus elicits as much resistance as conformity, when we make rules we call them nature, so that nonconformity can be stigmatized as unnatural. The proverbial wisdom, currently backed by some versions of sociobiology and evolutionary psychology, naturalizes the ideal of the loving nuclear family and condemns its failures. But the laws of nature have no history: they do not change. The proposition that family values emerged at a specific moment in the history of Western culture represents a refusal to accept the inevitability of certain norms.

As the figures for marital violence and cruelty to children emerge in our own society, it becomes increasingly apparent that the loving family, our culture's most cherished institution, is also too often a place of physical and psychological torment. Conceived as a stabilizing element in society, the family can equally be a source of deep-seated emotional instability. The history of the emerging ideal of the affective nuclear family in early modern England suggests that these contradictions may be structural, the result not so much of individual human weakness as of a problem at the heart of family values themselves.

My second aim is to treat Shakespeare's plays as the location of cultural history. Rather than isolated works of art, to be explained by reference to their context, these fictional texts may be seen to participate in the construction and affirmation of meanings in the period. And cultural history is above all a history of meanings. It has been a critical convention that we should interpret fiction in the light of its context. Scholars have read sermons, marriage manuals or domestic conduct books in order to explain what happens in the plays. By a strange reversal of values, however, this 'background', invoked to validate a specific reading, too frequently turns into the foreground, and in the process obscures features of the plays themselves. Are women enjoined to submission in the homiletic literature? It seems to follow that we are invited to condemn women who assert a position in the plays, however little support we find for this view in the fictional texts themselves.

My intention, by contrast, is to treat the plays as the material of cultural history alongside non-fictional texts of the period, rather than 
identify one as explanatory background to the other. When it comes to accounts of the family, domestic conduct books are no more neutral, impartial or authoritative, no more representative of their culture, than fiction. Where, indeed, could we find more detailed attention to the ambivalences of courtship, marriage and parenthood than in works designed to enlist and hold the attention of an audience by dramatizing the intense and intimate emotions of love and hate? Without assuming that the plays 'reflect' the world that produced them, we can be sure that they explore the meanings of the terms they construct and reiterate in ways that were expected to be at least partially intelligible to their original audiences. Meaning is never either single or static. To participate in a specific culture is to understand, reproduce, modify or transform, whether consciously or not, the polysemic signifiers in circulation there, and the plays cannot fail to take part in this process. Shakespeare and the Loss of Eden is an attempt to interpret, from the present, the complex, plural, contradictory character of a past culture as this is displayed in its texts.

Third, my plan is to analyse visual and written materials side by side. Poststructuralist theory is often criticized for privileging language. In practice, however, its concern is the signifying process, semiosis, whether in visual or in verbal form. Like words, pictures signify, and their spectators are invited to make sense of them. When we explicitly read a visual image, translate its meanings into words in order to give an account of it, something is necessarily lost. But when we interpret a verbal construct in words other than its own, there is also a loss. No less a component of culture than writing, and perhaps prior to it, the visual throws into relief the inadequacy as well as the solicitation of the reading process.

In the light of what we know now, the book sets out to trace representations of the emergence of the loving family in three linked fields: Shakespeare's plays, English visual culture of the sixteenth and seventeenth centuries, and interpretations of the Book of Genesis in the period. As early modern popular culture recounts, the primary Scriptural vindication of family values, the first loving marriage, ordained by God in the Garden of Eden, also led to betrayal, exile and the first murder, when Cain killed his brother because God preferred Abel. In Shakespeare, while marriage is synonymous with a happy ending, married love is shown to give way to murderous jealousy, and sibling rivalry leads to violence and death. The story of the nuclear family told in these texts and images, from romance through marital conflict to parenthood and the relations between the children, is both idealistic and sceptical. 
English family values emerged out of the religious, political and economic upheavals of the early modern period, when marriage based on love and consent was sanctified as a way of life for Christians, and the closeness of the family came to offer an alternative to the impersonal values of the emerging market. Many of the contradictions implicit in our own perception of the loving family were also evident at this inaugural moment: early modern accounts of the family put on display the twin possibilities of triumph and disaster. Precisely because of the promises it seems to make of perfect and shared happiness, now as then, the family also breaks hearts.

In the hope of naming something of this ambiguity, I have called the book Shakespeare and the Loss of Eden. Am I, then, charting a Fall? The answer is yes and no. I have no confidence in the myth that engrosses modernity of a lost golden world corrupted by time, or a founding moment from which the present has fallen away. The history of the transition from arranged to consensual marriage records, in my postmodern view, no moment of innocence, no high point of grace and no decline, but only specific joys and particular anxieties. On the other hand, family values represent for many people a utopian fantasy which, on closer inspection, is recognized as precisely utopian, realized nowhere. That recognition can bring desolation, the sense of exile from a destined happiness. But perhaps, the texts imply, Eden is an idea which in practice was always already lost.

I have incurred a great many debts in the course of writing, some very specific and some so extensive that my bare thanks here do not begin to balance the account. I am grateful to John Astington, Leeds Barroll, Judith Bennett, Peter Blayney, Kent Cartwright, Howard Cheetham, Stuart Clark, Peter Coss, James M. Dean, Alan Dessen, Cynthia Dessen, Tom Dawkes, Antony Easthope, Balz Engler, Geoffrey Fisher, Janette Graham, Stephen Greenblatt, Marshall Grossman, Richard Helgerson, Coppélia Kahn, Angela Locatelli, Lena Orlin, Elihu Pearlman, John Percival, Helen Phillips, Lois Potter, Susan Snyder, David Skilton, Yoko Takakuwa, Julia Thomas, Rachel Thomas, Ann Thompson, Charles Whitworth, Georgianna Ziegler. Helen Clifford has been a mine of information about material culture. I have borrowed shamelessly from Claire Connolly in my account of cultural history. I always come away wiser from my conversations with Barbara Mowat. And Susan Zimmerman has entered into the spirit of the quest with characteristic sympathy and enthusiasm.

I am grateful to the British Academy for support to attend the World Shakespeare Congress in Los Angeles in 1996, where I presented the first draft of Chapter 4, and for an award which made it possible to 
reproduce the illustrations. In June 1993 the University of West Virginia allowed me to explore some of the issues in a challenging and euphoric three-day Seminar. I am also grateful to the participants in a joint RCA-V\&A seminar in May 1996: they taught me more about cultural history in a single day than I can possibly acknowledge. My MA students at Cardiff University and my graduate class at UNC-Chapel Hill came up with ideas that repeatedly made me rethink my own. I have benefited from the expertise of the staff of the Rare Books Room at the University Library in Cambridge. The Arts and Social Studies Library at Cardiff University has been a constant and sympathetic resource. In 1991 I chaired a seminar at the Folger Institute in Washington DC, which was where it all began, and when in 1994 I held a Fellowship at the Folger Shakespeare Library, the kindness and the intellectual generosity of the staff and readers once again made the pursuit of sources a pure pleasure.

For the sake of consistency, I have modernized the spelling, typography and punctuation of quotations from early modern texts.

Parts of Chapter 2 appeared in Parallax. An earlier version of Chapter 3 was published in The Seventeenth Century.

Catherine Belsey 